\title{
Capitalizing on Nigeria's demographic dividend: reaping the benefits and diminishing the burdens
}

\author{
Holly E. Reed ${ }^{1}$ \\ Queens College, City University of New York (CUNY) and \\ CUNY Institute for Demographic Research (CIDR), New York, NY, USA \\ Blessing U. Mberu \\ African Population and Health Research Centre (APHRC), Nairobi, Kenya
}

\begin{abstract}
Nigeria is the most populous country in Africa and the eighth most populous country in the world, yet there is a dearth of published research about its demography. As Nigeria enters a period of potentially rapid economic growth due to the increase in the working-age population, it is critical to understand the demographic trends in the country. This paper examines the age and sex composition of Nigeria as it relates to various population characteristics using the two most recent Demographic and Health Surveys for Nigeria (2003 and 2008), as well as some data from the 2006 Census. It also highlights Nigeria's demographic composition and trends using United Nations population projection data, and its implications for the country reaping the demographic dividend. Finally, it draws some conclusions and makes some policy recommendations based on the findings.
\end{abstract}

Key words: Nigeria; demographic dividend; population growth; population policy

\section{Résumé}

Le Nigeria est le pays le plus peuplé d'Afrique et le huitième pays le plus peuplé du monde, mais il y a une pénurie de recherche publiée sur sa démographie. Comme le Nigeria entre dans une période de croissance économique potentiellement rapide en raison de l'augmentation de la population en âge de travailler, il est essentiel de comprendre les tendances démographiques dans le pays. Cet article examine la structure par âge et sexe de la population du Nigeria et sa relation avec d'autres diverses caractéristiques de la population à l'aide des deux plus récentes enquêtes démographiques et de santé (2003 et 2008), ainsi que certaines données du recensement de 2006. Il met également en évidence la structure démographique et l'évolution de la population du Nigeria à partir des données de projection de la population des Nations Unies, et ses implications quant à la possibilité pour le pays de bénéficier d'un dividende démographique. Enfin, il tire des conclusions et fait des recommandations pour les politiques à partir des résultats présentés.

Mots-clés : Nigeria, dividende démographique, croissance démographique, politique de population

\section{Introduction}

Nigeria's population and resources are vast, but its challenges loom equally large. The country is on the verge of experiencing a potential demographic dividend, or the economic growth due to the increase in the share of a country's population in the working ages (and the corresponding decline of those in the non-working ages). If Nigeria adopts the most appropriate and effective policies, it can capitalize on its natural advantages to address current challenges while promoting future economic growth and social development and becoming not only an African, but a global leader. Investments must be made in this growing labor force, as well as future generations, to ensure that the Nigeria's course of development proceeds in a positive direction.

Nigeria is the most populous country in Africa and the eighth most populous country in the world, with approximately 162 million people. Despite declining fertility, Nigeria's population is expected to continue to grow to 239 million by 2025 and 440 million by 2050 due to population momentum, making it then the $4^{\text {th }}$ most populous country in the world (United Nations 2012). Most of this growth will be people in the working ages, between age 15 and 64 . Thus, the dependency ratio, or the number of children and elderly (under age I5 and over age 65) divided by the number of working age adults (between ages 15-64), will fall over this period from 88 dependents per 100 workers in 2010 to only 69

I. Correspondence address: Holly E. Reed, Department of Sociology, Queens College, Powdermaker Hall 252, 65-30 Kissena Boulevard, Queens, NY II357, USA; Telephone: +I-7I8-997-2828; Fax: + I-7I8-997-2820; E-mail: Holly.Reed@QC.CUNY.EDU 
dependents per 100 workers by 2050 . The median age of the total population is likewise anticipated to increase from 17.9 to 21.4 years over the 40 -year period from 2010 to 2050 (United Nations 20I2). These trends are of particular importance because Nigeria is expected to make up three percent of the total world population and 14 percent of Africa's population by 2050 (United Nations 2008). Thus, Nigeria will be poised to be a major player in the global system, and particularly important in the African region. In addition to its valuable human capital, Nigeria's oil and gas resources represent a potential development boost. Nigeria contains 37 billion barrels of proven oil reserves (CIA 2009) and 5 trillion cubic meters of natural gas reserves (Ross 2003). It is already ranked among the top 13 oil producers globally (Akpan 2006) and produced 34 billion cubic meters of gas in 2007, exporting 21 billion (CIA 2009). Yet despite these tremendous resource advantages, Nigeria continues to lag behind on many development indicators. Why? Primarily Nigeria has not properly invested in its current and future labor force, nor has it developed its oil and gas industries to produce long-term growth in both jobs and GDP, nor has it diversified its economy (World Bank/DFID 2005).

Will Nigeria's current and future population composition be a benefit or a burden? How might Nigeria's relative share of working age persons (1564) and dependents (under 15 and 65 and over) contribute to long term economic growth and development? The economic growth potential posed by the demographic transition is created by a decline in mortality that precedes a large decline in fertility. This period of lower mortality and higher fertility, often known as a baby boom, will ultimately lead to a working age bulge or a potential demographic dividend when this large cohort of children grows up. However, whether the working age bulge constitutes a dividend or not also depends on the availability of employment. A country's dividend cannot be realized if there is widespread unemployment among its working age population. This is because those outside the labor force consume part of what is produced by the currently employed, and this influences the amount of surplus that is available for investment after consumption. A larger surplus can lead to increased investment and increased economic growth, therefore, assuming that jobs are available, a lower dependency ratio is an advantage.

This paper aims to examine the age and sex composition of Nigeria as it relates to various population characteristics, including level of urbanization, educational attainment, household structure, wealth, religion, ethnicity and language, and employment and occupation. Based on this analysis, some key findings and policy recommendations related to population policy - as well as broader social and economic development - are presented.

Following the introduction, we present findings from the $2008 \mathrm{DHS}$, along with comparisons to the 2003 DHS, to examine the current status and trends of Nigeria's population age and sex composition, particularly as it relates to the socioeconomic status, household composition, religion and ethnicity/language and employment and occupation, and family planning needs.

Nigeria's demographic composition and trends based on United Nations population projection data and its implications for its demographic dividend are presented next. Finally, the last section of the paper, summarizes key findings, draws conclusions and presents policy recommendations.

\section{Nigeria's population structure and the demographic dividend}

In this section of the paper, we use the 2008 DHS data with some comparisons to the 2003 DHS data (and occasionally the 2006 Census data and some UN data) to describe the basic current demographic profile of Nigeria and to compare how education and employment vary by region, rural or urban residence, religion, language and ethnicity, human capital attainment and wealth. Univariate and bivariate tables are presented and analyzed here; values are weighted for sampling probabilities. The DHS data are presented by topic (i.e., employment, education) in tables for men, women and the full sample (2003 and 2008). Although it is not possible to fully discuss every statistic in these tables, major gender differences are summarized. Note that the DHS collects data from women aged 15-49 and eligible men in the same households aged 15-59; only data for those aged 15-49 are displayed for comparability across the sexes. All data are weighted to represent the population.

\section{Population distribution and characteristics}

The 2006 National Census estimated the total national population at $140,431,790$. The states of Kano (in the north) and Lagos (in the south) were by far the largest in terms of population, with 9.4 million and 9.1 million people, respectively. Other large population centers (over 5 million) in Nigeria included: Kaduna with 6.1 million residents, Katsina with 5.8 million, Oyo with 5.6 million, and Rivers with 5.2 million. Looking at larger regions of the country, the estimates from the 2008 DHS are that the largest percentage of the population lives in the North West (24 percent), followed by the South South (with about 21 percent) and South West (17 percent). The North East region has declined since 
2003 from 18 percent to only 12.5 percent. The general trend is that population is declining in the northern areas and increasing in the south (National Population Commission 2006).

According to our tabulations of the 2008 DHS, approximately 64 percent of the population lives in rural areas, and only 36 percent in urban areas (National Population Commission [Nigeria] and ICF Macro 2009). The UN estimate for 2010 was 49.8 percent urban, which is significantly higher than the DHS figures (UN 2009). As shown in Figure I, it is also projected to increase quite rapidly, with over the half the population living in urban areas by 2015 and over three-quarters of the population living in urban areas by 2050 (UN 2009). These vast discrepancies between the two sources of data remain a key challenge to research in the country and investments in estimation and projection techniques to generate credible data on population dynamics and outcomes may be an important effort in understanding the demographic process and associated potential dividends in Nigeria.

In terms of growth, as shown in Figure I, the UN estimates that the urban population in Nigeria is growing currently at a rate of about 3.75 percent, and it will continue to grow at a rate of at least 3.26 percent annually through 2025 to 2030 and 2.60 percent between 2045 and 2050 (UN, 20I2). Mean- while, the growth rate for the rural population is already at 1.2 percent and expected to continue to decline, reaching less than 1.0 percent growth by 2025 and 0.24 percent by 2045-through 2050 (UN, 20I2). While this seems quite low, considering the high rural fertility rates, it suggests that mortality may be much higher in some rural areas than in urban areas. Note that rural residents probably generally have poorer health and lower life expectancies than urban residents (with the exception of some slum populations) (Montgomery et al. 2003), although no research from Nigeria is available that supports this possibility.

In general, natural increase (fertility minus mortality) represents a greater share of urban growth in sub-Saharan Africa than it does in other regions (Chen et al. 1998), so these urban growth rates in Nigeria likely capture relatively high (although now declining urban fertility rates). Although urban growth was higher in Africa than in the rest of the world, the continent still experienced an overall decline in urban growth during the 1990s and 2000s (Potts 2006; Bocquier 2005; Bocquier 2003; Potts 2000; Potts 1995), which corresponds with the UN estimates. Recently researchers have suggested that the UN urban projections for both Nigeria and subSaharan Africa overall are much too high (Potts 2012; Bocquier and Mukandila 20I I).

Figure 1 Percentage urban and rural in Nigeria, United Nations data (2009 revision)

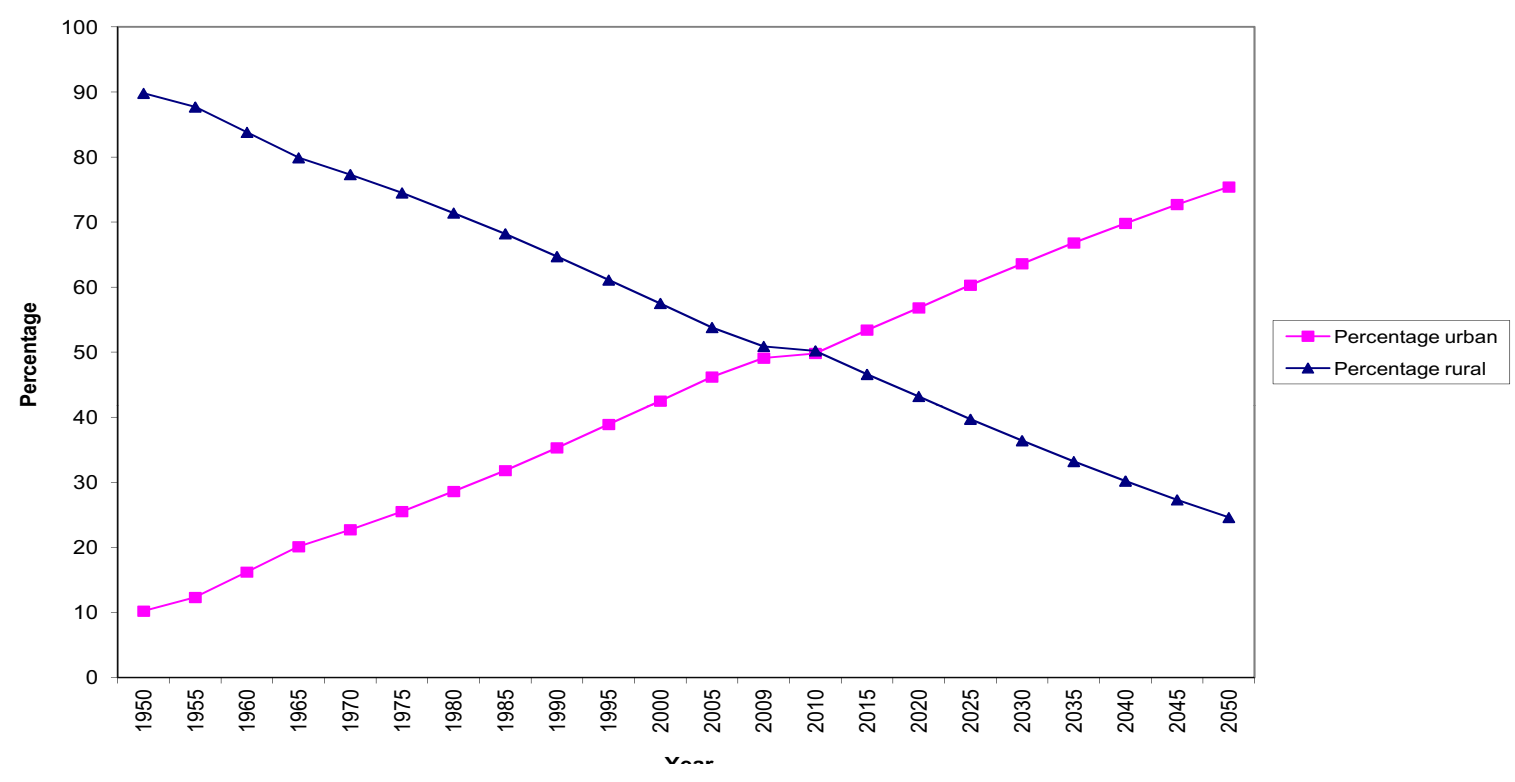

Figure I Percentage urban and rural in Nigeria, United Nations data (2009 revision)

Nevertheless, even if these projected rates are not exactly right, one can anticipate that the percentage of Nigeria's urban dwellers will increase while the percentage of rural dwellers will decrease over time. 
Addressing the needs of these increasing numbers of urban residents, including their access to food, housing, education, employment and services will be a major challenge for Nigeria's government in the coming decades and will be critical in harnessing the benefits of her demographic dividend. Some of these new urban residents will be migrants from rural areas (Mberu 2005), so there will likely be additional challenges in integrating them into the cities, but many will be the children of current urbanites, as natural increase (fertility) is also contributing to urbanization. The characteristics of urban populations will be examined in turn in each of the follow- ing sections.

\section{Age and sex structure}

Table I shows the age and sex structure of the national population according to the 2006 census data. It is clear at first glance that the majority of the population is younger than 30 years old. In fact, about 70 percent of the population is under age 30 and about $4 \mathrm{I}$ percent of the population is younger than age 15 . This is a very large cohort of young people, and particularly of young children, who will be entering the educational system and then the labor force (under an ideal scenario).

Table I Distribution of population by age groups and sex, Nigeria 2006

\begin{tabular}{llll}
\hline Age groups & Both sexes & Males & Females \\
\hline $0-4$ & $22,594,967$ & $11,569,218$ & $11,025,749$ \\
$5-9$ & $20,005,380$ & $10,388,611$ & $9,616,769$ \\
$10-14$ & $16,135,950$ & $8,504,319$ & $7,631,631$ \\
$15-19$ & $14,899,419$ & $7,536,532$ & $7,362,887$ \\
$20-24$ & $13,435,079$ & $6,237,549$ & $7,197,530$ \\
$25-29$ & $12,211,426$ & $5,534,458$ & $6,676,968$ \\
$30-34$ & $9,467,538$ & $4,505,186$ & $4,962,352$ \\
$35-39$ & $7,331,755$ & $3,661,133$ & $3,670,622$ \\
$40-44$ & $6,456,470$ & $3,395,489$ & $3,060,981$ \\
$45-49$ & $4,591,293$ & $2,561,526$ & $2,029,767$ \\
$50-54$ & $4,249,219$ & $2,363,937$ & $1,885,282$ \\
$55-59$ & $2,066,247$ & $1,189,770$ & 876,477 \\
$60-64$ & $2,450,286$ & $1,363,219$ & $1,087,067$ \\
$65-69$ & $1,151,048$ & 628,436 & 522,612 \\
$70-74$ & $1,330,597$ & 765,988 & 564,609 \\
$75-79$ & 579,838 & 327,416 & 252,422 \\
$80-84$ & 760,053 & 408,680 & 351,373 \\
$85+$ & 715,226 & 404,021 & 311,204 \\
Total & $140,431,790$ & $71,345,488$ & $69,086,302$ \\
\hline
\end{tabular}

The sex ratio (ratio of males to females) is generally greater than one for children, but it reverses in the 20s, when there are somewhat more females than males, and then reverses again in the 40s, when there are more men than women up through the oldest ages. This suggests some potential son bias, as well as a potential older age bias. Male mortality among young adults may be quite high as well, especially in light of high maternal mortality rates for young adult females. However, the data are somewhat suspect and further analysis is required to truly understand the sources of these sex ratio differences. It is not possible to compare these numbers directly with the DHS data, because about three times as many women as men were interviewed in that survey. Nevertheless, the DHS, although it includes only ages 15-59 (focusing on women of reproductive age, 15-49), does show a very young age structure as well; about 54 percent are under age 30 in 2008.

\section{Other socio-demographic characteristics}

Nigeria is primarily a Muslim and Christian country; in 2008, about 45 percent reported Islam as their religion, I I.5 percent were Catholic, and about 42 percent were Other Christian (either Protestant or another Christian denomination). The percentage of Catholics and other Christians declined somewhat 
between 2003 and 2008, while the percentage of Muslims increased from 37.4 to $44.7 \%$ (NPC and ICF Macro 2009). Some regions of the country, including the North East and North West are almost entirely Muslim, while the South East has a predominance of Catholics, and the South South has a majority of other Christians.

There are a great number of ethnic-linguistic groups in Nigeria, although the main languages are Hausa (primarily spoken in the northern regions), Yoruba (primarily spoken in the South West), Igbo (primarily spoken in the South East), and English. Yet many other languages have large contingents; over half of Nigeria's population claims a native language other than one of these four (NPC and ICF Macro 2009).

Table 2 Summary characteristics of the sample by sex

\begin{tabular}{|c|c|c|c|c|c|c|}
\hline & \multirow{2}{*}{\multicolumn{3}{|c|}{$\begin{array}{l}2003 \text { DHS } \\
\% \text { or Mean }\end{array}$}} & \multirow{2}{*}{\multicolumn{3}{|c|}{$\begin{array}{l}2008 \text { DHS } \\
\% \text { or Mean }\end{array}$}} \\
\hline & & & & & & \\
\hline & Males & Females & Total & Males & Females & Total \\
\hline Mean age & 33.2 & 28.6 & 29.8 & 31.8 & 28.7 & 29.7 \\
\hline Mean total years of education & 8.6 & 6.4 & 7.0 & 8.0 & 6.2 & 6.8 \\
\hline Worked last year & 78.8 & 63.8 & 67.8 & 83.7 & 61.1 & 68.7 \\
\hline Urban residence & 39.3 & 39.3 & 39.3 & 37.3 & 35.8 & 36.2 \\
\hline Mean number of household members & 5.7 & 6.5 & 6.3 & 5.5 & 6.3 & 6.0 \\
\hline Male household head & 91.4 & 80.9 & 83.7 & 93.1 & 81.8 & 85.4 \\
\hline Mean age of household head & 43.1 & 44.4 & 44.1 & 42.9 & 44.7 & 44.1 \\
\hline
\end{tabular}

On average, women are much less educated than men, although there seems to be some improvement for both sexes. According to the 2008 DHS, about 36 percent of women have no formal schooling (down from about 42 percent in 2003), 20 percent have only primary education (21\% in 2003), 36 percent have secondary education (up from $31 \%$ in 2003), and about 9 percent have higher than secondary education (up from $6 \%$ in 2003). Men in the DHS show a similar pattern, but with less dramatic changes over time: only 21 percent have no formal schooling (22\% in 2003$), 21$ percent have primary schooling (down from 26\% in 2003), 43 percent
Table 2 shows some summary characteristics of the 2003 and 2008 DHS samples: mean age and years of education, employment, urban residence, and household characteristics. Educational attainment in Nigeria remains low, and according to the Census, about 47 percent of the population is illiterate (NPC 2006). The 2003 DHS found that about 36 percent of the population had no formal schooling. However, there is some evidence that this situation is improving; both the 2006 Census and the 2008 DHS found that only about $3 \mathrm{I}$ percent of the population had no formal schooling, a decline of five percentage points from 2003. In 2003, only 19 percent of the population completed secondary school or higher education, but by 2008 , this figure increased substantially to about 30 percent. have secondary education (up from $41 \%$ in 2003), and 14 percent have higher education (up from $12 \%$ in 2003). The mean years of education appear to have decreased between the two DHS surveys, which may indicate poor educational policy and implementation of programs or poor data quality.

According to both DHS surveys, the majority of both men and women worked last year, but more men than women worked in both survey years. Employment seems to be down slightly for both men and women between 2003 and 2008, but is over 65 percent total. Nearly 40 percent of Nigerians live in urban areas. 


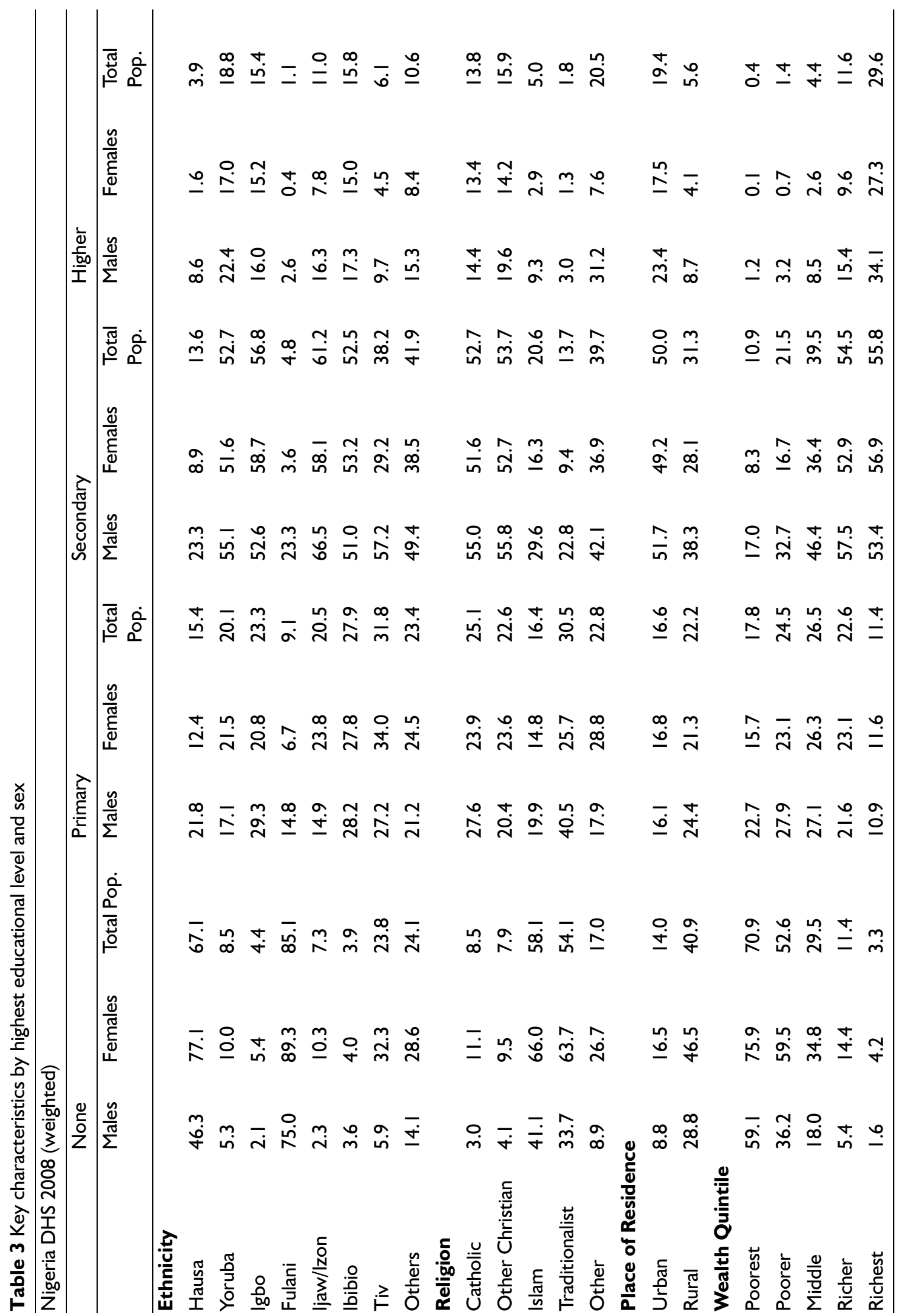


Approximately 85 percent of households in the DHS are male-headed in 2008 (compared to about 84 percent in 2003), and the mean age of the household head was approximately 44 years in both years. According to the 2006 Census, the average household size is large, with over 72 percent of households having at least five people. Mean household size in the DHS surveys confirms this. Marriage is relatively universal in Nigeria and those who are widowed or divorced at younger ages often remarry.

\section{Education}

As Table 3 (above) shows, according to the 2008 DHS there is also a clear religious gradient in education. Catholics and Other Christians have fairly high levels of educational attainment overall (over 65 percent have secondary or higher education). Meanwhile, Muslims and traditionalists have relatively low levels of educational attainment, although Muslims have somewhat larger percentages of secondary or higher level attainment compared to traditionalists. Over 50 percent of both Muslims and traditionalists have no formal schooling.

Not surprisingly, urban residents have higher levels of education than their rural counterparts. Sixtynine percent of urbanites have secondary or higher levels of education, while only about 37 percent of rural dwellers do. Educational access is more difficult in rural areas, as there are fewer schools and fewer resources, in addition to the tradition that rural children are often kept from attending school to help with agricultural or home chores (Montgomery et al. 2003; UNESCO 2000; Enaohwo 1983). As the data in Table 3 also demonstrate, there is a clear positive relationship between wealth and educational attainment, with the middle and richer quintiles having higher percentages of people who have attained secondary or higher levels of education compared to the poorer quintiles. In sum, women, and those living in rural areas, those living in the northern part of Nigeria, Muslims and traditionalists, and the poor are worse off in terms of formal educational attainment. In relation to maximizing the demographic dividends, addressing these educational disadvantages among these disadvantaged groups will be uppermost for Nigeria currently and in the years to come.

\section{Employment}

Table 4 (below) shows results for employment and occupation by age, sex, region, type of place of residence, and educational attainment using the 2008 DHS data. (Note that many of these values do not sum to 100 percent because of missing values for occupation.) The first column shows the percentage not working by various characteristics. Unemployment rates are quite high among the younger age groups; 66 percent of teenagers were not working in 2008 , possibly because many are in school, but also undoubtedly due to high youth unemployment. This percentage has declined substantially since 2003, when it was 73 percent. Unemployment seems to have declined over the five-year period from 20032008 among all age groups, which is a good sign. Yet, it is only after age 30 that unemployment rates drop below 25 percent. Unemployment was relatively high in all regions, but lowest in the South South and highest in the North West. In 2008, 32 percent of urban residents were unemployed, and about 30 percent of rural residents. The connection between education and employment is a mixed picture. Unemployment is, somewhat counter intuitively, lowest among those with primary education (18 percent) and highest among those with secondary education (38 percent). This potentially suggests that those who either attend but do not complete secondary school and/or those who complete secondary school are at a disadvantage on the job market, while there are still enough jobs for those with at least some primary education in Nigeria. Unemployment is relatively high (at least 17 percent) among all educational groups, however, there is likely a need to create jobs at all skill and educational levels.

Looking at occupational distributions, there are relatively low percentages employed in clerical work and unskilled manual labor across all age groups and other socio-demographic categories. Those in the younger age groups are most likely to be employed in agriculture or sales. In the older age groups, people are also generally employed in agriculture or sales, but there are larger percentages also in professional or technical work and skilled manual labor. There is an urban-rural divide in occupational distributions as well. The highest percentage of workers is found in sales occupations in urban areas, and in agriculture in rural areas. Skilled manual labor, household and domestic, and professional or technical jobs also make up large percentages in urban areas, while sales and skilled manual labor jobs are also important in rural areas. As seen in the previous section, educational levels are higher in urban areas, so this coincides with the distribution of occupations by educational attainment. According to the 2008 DHS, 33 percent of those with higher education are in professional and technical jobs (down substantially from 44 percent in 2003), and 18 percent are in sales (up from about 10 percent in 2003). This suggests that fewer university graduates are finding jobs commensurate with their training. Likewise, over a quarter of those with completed secondary educations are in sales, but relatively large percentages are also in agriculture, household and domestic, and skilled manual labor. Most with primary or no education who work are in sales, agriculture, and, to a lesser extent, skilled manual labor. 


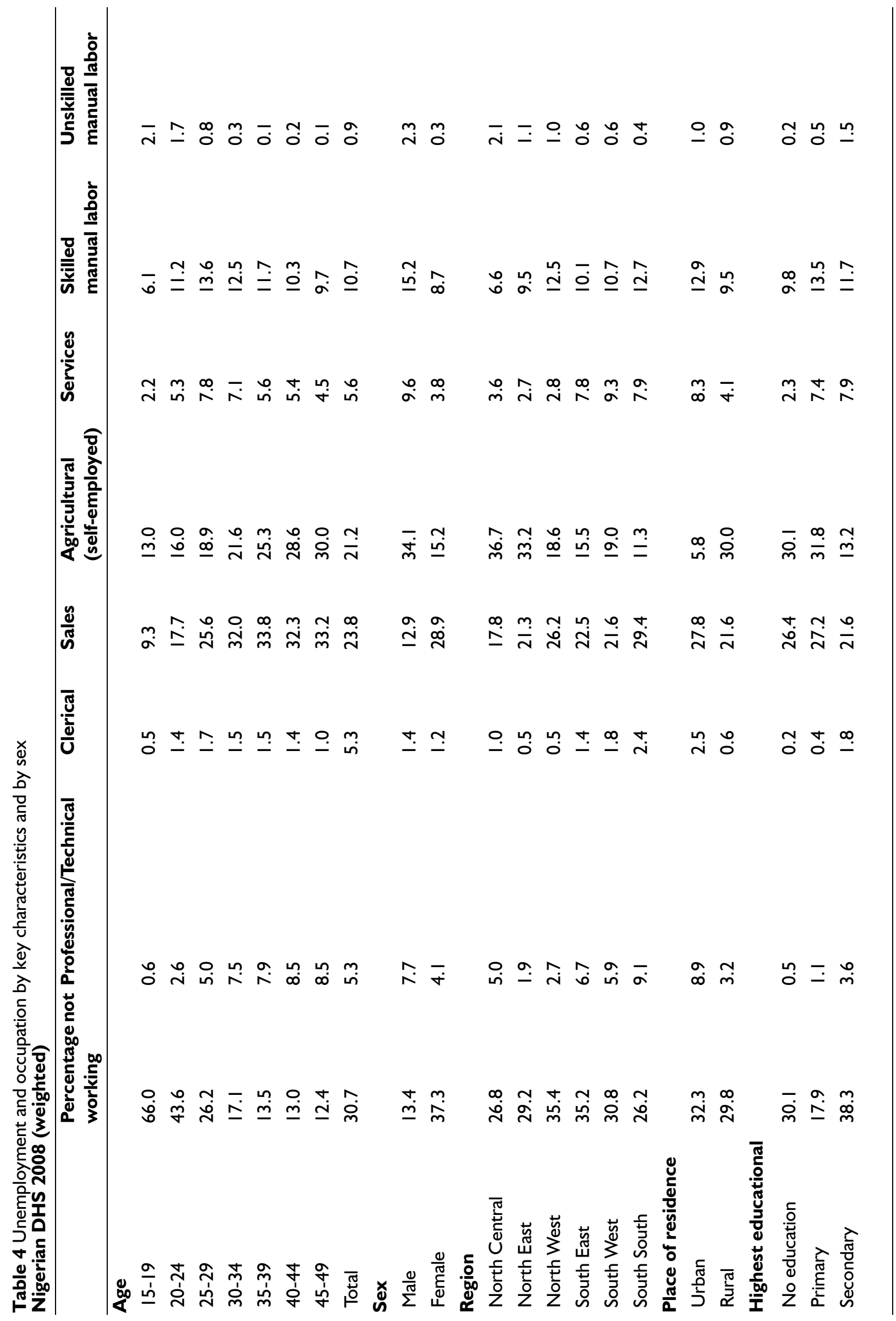


Although further analysis of the labor market and economic situation is needed, these descriptive statistics seem to suggest that there may be a significant number of Nigerians with secondary or higher levels of education who are underemployed in sales, agriculture, or skilled manual labor. Women's labor force participation is far behind men's, likely because of high rates of childbearing, particularly at young ages, when women might first enter the labor market. These results point to the persistence of female labor force disadvantages identified in the country in the last 20 years. The World Bank (1996) identified the legal, regulatory, and cultural barriers that keep women disadvantaged relative to men in terms of access to health, education, financial, and agricultural extension services. Similarly, apart from facing discrimination in employment, Adeyeye (1996) and Haddad (199I) had highlighted how women also face lower chances of independent escape from poverty, in part because women's large share of domestic commitments prevents them from seizing new and profitable opportunities as readily as men.

Urban and rural unemployment were similar in 2003, but now urban unemployment is higher than that in rural areas. As urbanization proceeds at a rapid pace in Nigeria, there will be even more urban unemployment if jobs are not created for the millions of young people-both urban residents and migrants to urban areas - who will be finishing their educations and entering the labor market for the first time.

Unemployment appears to be high across the entire country, so the development of industries and employment must have a national focus (albeit with regionally appropriate components), and not just focus on one or two potential areas for job creation in one or two regions. Agricultural employment seems to be the main force that is reducing unemployment, but this should only be seen as a positive trend if wages and income for farmers are well above subsistence level. In addition, increasing employment in agriculture may lead to other problems in the long run if agriculture is not developed in an ecologically sound manner. Several researchers have noted the negative environmental impacts of common agricultural practices like slash and burn in Nigeria (Junge et al. 2008; Onwuka 2005).

\section{Nigeria's population projections and implications for demographic dividend}

The UN projections assume that Nigeria is currently a medium-fertility country; in other words, although fertility is still well above replacement level, it is declining and expected to continue to decline. How- ever, because Nigeria's TFR is currently still over 5 children per woman, even with the assumption of a steady decline, it is still not expected to reach replacement level fertility by the end of the projection period, 2050. This is under the medium-variant assumption. Under the high-variant assumption, fertility will remain even higher, by approximately 0.5 children per woman throughout the projection period. Under a low-variant assumption, the opposite is true; fertility is expected to remain lower, by approximately 0.5 children per woman through 2050 (UN, 2009). While this range may seem small, it can have a substantial impact in a country like Nigeria with currently high fertility; if fertility declines more rapidly, according to the low-variant assumption, Nigeria could reach replacement level fertility by 2050 , but if fertility declines slow or stall, then fertility could still be as high as about 3 children per woman by 2050.

In terms of mortality assumptions, Nigeria is one of the high-HIV-prevalence countries (having a prevalence among persons aged $15-49$ of at least 1.0 percent during the period 1980-2007; Nigeria's current estimated prevalence is about 3.1 percent (UNAIDS 2008)). Therefore, mortality for Nigeria is projected by modeling the course of the AIDS epidemic and projecting a yearly incidence of HIV infection. However, the models also assume a 50 percent reduction in the force of the epidemic and the population at risk of infection every 20 years, due to assumed behavioral changes. The models also make countryspecific assumptions regarding the impact of antiretroviral therapy treatments, mother-to-child transmission treatments, and pediatric AIDS therapies (UN 2009). Despite stated government priorities in tackling the HIV/AIDS epidemic and international donors increased funding (DFID, 2004), universal access to HIV prevention, treatment, care, and support remains to be attained in the country. Nigeria's current life expectancy is only 49 years, and although it is projected to increase, it will only rise to about 62.5 years by 2050 . Consequently, Nigeria must step up its efforts to attack the AIDS crisis to prevent an even bleaker picture of future life expectancy in the next round of UN projections.

\section{Conclusions and policy recommendations}

With respect to its age structure, at first glance Nigeria appears to be in a very promising situation overall, with a large cohort of young people entering adulthood (and, presumably, the labor force) while fertility rates are falling. Nevertheless, the population of children and youth will still be quite a large 
(albeit declining) percentage of Nigeria's total population by 2050 ( 28 percent). Even though the percentage of elderly will be relatively small, the elderly population is projected to grow and the numbers of both youth and elderly are staggering, given the overall population of Nigeria. Policies must address the needs of these groups, including education, child immunizations and basic health care, the prevention of sexually transmitted diseases and reproductive health services for teens, and old-age support and pensions and health care for the elderly who are disabled or chronically ill.

The dependency ratio suggests that the working age population will support these other two portions of the population, and in fact produce a surplus, but in order to do that, they must be employed, and the data presented in this paper make that prospect seem rather dim. Despite some improvement between 2003 and 2008, unemployment rates are very high across nearly every region and every subgroup in the population. Increased employment seems to be mainly agricultural, which may not provide enough income to adequately support Nigerian families and could have deleterious environmental consequences if not done properly.

In terms of population trends, Nigeria's total fertility rate (TFR) remains quite high compared to the rest of the less developed countries (over 5 children per woman) and although it is projected to continue to decline, there are questions about whether this decline is inevitable and whether it will continue apace. There is some evidence of decline from the 2003 and 2008 DHS data, however. Regardless of how the fertility rate changes, Nigeria's population growth will continue through 2050 due to simple population momentum.

Age at first sex, age at first marriage, and age at first birth for women still remain low in Nigeria (17.2, 17.8, and 19.4, respectively, according to the 2008 DHS), although they have increased since 2003. Policies must be implemented that raise these average ages to reduce fertility overall. Unmet need remains high and the public health infrastructure particularly the family planning and reproductive health infrastructure - is in great need of reform and improvement (Blattner et al. 2008). Confronting and assuaging Nigerian pronatalist attitudes, particularly among men, is potentially difficult, but also necessary. This requires investment in education for women and an overall focus on improving the status of women. But investment in education, particularly for women, does not make sense without a benefit in terms of employment and economic mobility.

The labor market currently does not have many opportunities for women (or men, for that matter) and underemployment is widespread as well, partic- ularly for youth (World Bank 2009). What can be done? This is a question for the development economists, but it would seem that at this point in time, with the current technological resources available and Nigeria's substantial oil wealth, some creative forms of education, training, and job creation should be a focus.

Key subgroups within the population deserve special emphasis in population and economic policies. Ethnic disparities in fertility and child morbidity and mortality rates have been documented and are linked to religious, regional, and socioeconomic disparities, as well as some cultural practices (Reed and Mberu, forthcoming; Olufunke and Obafemi 20lI). The northern regions, Muslim and traditionalist populations, and rural areas, in particular, are in need of increased resources and infrastructure, particularly in the areas of family planning, education (especially female education), job creation, and public health. These programs should not exclude other regions or parts of the population, particularly as Nigeria is rapidly growing and there is also a large and growing urban population base in the south. Supporting change in underserved areas and among underserved groups without alienating those who are somewhat better off will require stronger governmental and civil society institutions (Bloom et al. 2007).

Although we do not discuss them in detail in this paper, Nigeria's mortality and health indicators continue to lag far behind other countries as well. Life expectancy lags severely, due to the HIV/AIDS epidemic as well as other infectious diseases, and poor health care infrastructure, particularly in rural areas (Blattner et al. 2008). The facilities in the Nigerian health system are unevenly distributed across the country's regions and most of the facilities are clinics, not hospitals (and most hospitals are privately owned), with an inadequate supply of trained health workers (Nwakeze and Kandala 20II). A recent analysis by Akinyemi et al. (20/3) found that child survival rates improved between 1990 and 2008, but that this improvement was due primarily to improvements in sewage disposal and drinking water, as well as birth spacing and child care. In order to further decrease child mortality rates, the authors argue that maternal and child health services must be expanded and female education increased. Steps are being made in the right direction, but massive public health investments, such as the government's ongoing recruitment of midwives for rural areas, must be made to avoid Nigeria falling even further behind its neighbors in life expectancy and health (Akinyemi et al. 20I3).

If the UN projections can be believed, continuing urbanization, at least partially due to internal migra- 
tion from rural areas, but also natural increase within cities, means that urban labor markets will need more jobs and infrastructure over time. Will this increasing urbanization lead to a more rapid fertility decline? Perhaps, as urban fertility norms continue to decline and rural migrants assimilate to urban norms (see, for example, White et al. 2008). But it is important to recognize that even if urban fertility declines without many policy changes, Nigeria's rural population will still be large in numbers (even if they are a declining percentage of the population), rural-rural migration remains high (Mberu 2005), and rural fertility change may require significantly more intervention.

In terms of international migration, Nigeria has moved from being primarily a sending country to also being a migrant receiving country in the West African region (Adepoju 20II). Meanwhile, the Nigerian diaspora continues to grow globally, but although Nigeria is a leader in terms of the volume of remittances received from the diaspora in Africa, data on how these funds are used was lacking until recently; moreover, the country is also losing remittances sent out by non-Nigerian nationals resident in the country (Afaha 20I3). Whether or not the Nigerian diaspora is a potential engine for growth at home or simply a brain drain is an outstanding question; however, the organization Nigerians in Diaspora Organizations has been formed and is in active dialogue with the Nigerian government regarding development and remittances (Adepoju 20II).

The demographic dividend as a potential boon for overall development was first recognized in the case of the East Asian tigers. There is some debate in the literature about whether or not Africa can follow their model and capitalize on this one-time demographic bonus of a large working age population and relatively small dependent population (World Bank, 2009; Bloom et al. 2007; Bloom et al. 1998). It is a tall order, particularly for a country like Nigeria, given all of its challenges as highlighted in this analysis. Nevertheless, Nigeria's population, in combination with its relative wealth, could be a dynamic engine of growth if harnessed properly. The Nigerian government, as well as international donors, must focus on the key challenges of investing in basic public infrastructure, including health, family planning, schools, and basic services; and of reinvesting oil profits in job creation. These sound like simple prescriptions, but of course they are not. Nevertheless, time is passing quickly and unless these investments are made now, the demographic dividend and its golden opportunity will pass Nigeria by. An important part of this process must include investments to improve quality data collection, access and availabil- ity, and the promotion of research on Nigeria's demographic trends and processes in order to generate credible evidence to guide policy and program interventions as well as to monitor and evaluate progress.

\section{Acknowledgements}

Thank you to Catherine S. Andrzejewski, Robert L. Reed, Gabriel Saldarriaga, and Guillermo Yrizar-Barbosa for their research and editorial assistance. We also thank David Bloom and two anonymous reviewers for their helpful comments.

\section{References}

Adepoju, A. 20I I. "Reflections on international migration and development in sub-Saharan Africa," African Population Studies 25(2):298-319.

Adeyeye, V. A. (1996). The impact of new technology on poverty level of rural women. Technical Report. New York: Carnegie.

Afaha, J.S. 2013. "Migration, remittance and development in origin countries: Evidence from Nigeria," African Population Studies 27(I):53-69.

Akinyemi, J.O., E.A. Bamgboye, and O. Ayeni. 2013. "New trends in under-five mortality determinants and their effects on child survival in Nigeria: A review of childhood mortality data from 1990-2008," African Population Studies 27(I):25-42.

Akpan, W. 2006. "Between responsibility and rhetoric: some consequences of CSR practice in Nigeria's oil province," Development Southern Africa 23(2).

Blattner, W., P. Dakum, B. Osotimehin, A. Nasidi, and A. Abimiku. 2008. "Public Health Aspects of HIV/AIDS: Nigeria and West Africa," pp. 2 I7-25 I in D. Celentano and C. Bayrer, eds., Public Health Aspects of HIV/AIDS in Low and Middle Income Countries. New York: Springer.

Bloom, D.E., D. Canning, G. Fink, and J. Finlay. 2007. "Realizing the demographic dividend: Is Africa any different?" Paper prepared for the Program on the Global Demography of Aging, Harvard University, May 2007.

Bloom, D.E., J.D. Sachs, P. Collier, and C. Udry. 1998. "Geography, demography, and economic growth in Africa," Brookings Papers on Economic Activity 1998(2):207-295.

Bocquier, P. 2005. "World urbanization prospects: An alternative to the UN model of projection compatible with urban transition theory." Demographic Research 12(9): 197-236.

Bocquier, P. 2003. "Analyzing urbanization in Africa," pp. I33-I50 in G. Hugo and A. Champion, eds., New Forms of Urbanization. Aldershot: Ashgate. 
Bocquier, P., and A.K. Mukandila. 20I I. "African urbanization trends and prospects," African Population Studies 25(2):337-36I.

Chen, N., P. Valente, and H. Zlotnik. 1998. "What do we know about recent trends in urbanization?" pp. 59-88 in R.E. Bilsborrow, ed., Migration, Urbanization and Development: New Directions and Issues. Norwell, MA: UNFPA-Kluwer Academic Publishers.

CIA. 2009. CIA World Factbook: Nigeria. Available at: http://www.cia.gov/library/publications/the-worldfactbook/geos/ni.html, accessed: Monday, October 19, 2009.

DFID. 2004. Country Assistance Plan for Nigeria, 2004-2008. London: DFID.

Enaohwo, J.O. 1983. "Resource distribution in Nigerian secondary schools: issues of urban-rural inequality," Educational Review 35(I):25-33.

Haddad, L. (I99I). Gender and poverty in Ghana. IDS Bulletin, 22, 5 - 16.

Junge, B., R. Abaidoo, D. Chikoye, and K. Stahr. 2008. "Soil conservation in Nigeria: Past and present on-station and on-farm initiatives." Soil and Water Conservation Society. Ankeny, lowa.

Mberu, B. 2005. "Who moves and who stays? Rural out-migration in Nigeria," Journal of Population Research 22(2): I4I-I6I.

Montgomery, M., R. Stren, B. Cohen, and H. Reed, eds. 2003. Cities Transformed: Demographic Change and Its Implications in the Developing World. Washington, DC: National Academies Press.

National Population Commission (NPC) [Nigeria]. 2006. 2006 Population and Housing Census of the Federal Republic of Nigeria. Abuja, Nigeria: National Population Commission.

National Population Commission (NPC) [Nigeria] and ICF Macro. 2009. Nigeria Demographic and Health Survey 2008. Abuja, Nigeria: National Population Commission and ICF Macro.

Nwakeze, N.M., and N-B. Kandala. 20I I. "The spatial distribution of health establishments in Nigeria," African Population Studies 25(2):680696.

Olufunke, F., and O. Obafemi. 20II. "Ethnicity and child survival in Nigeria," African Population Studies 25(I):92-II 2.

Onwuka, E.C. 2005. "Oil extraction, environmental degradation and poverty in the Niger Delta region of Nigeria: A viewpoint." International Journal of Environmental Studies 62(6):655-662.

Potts, D. 2012. "Challenging the myths of urban dynamics in sub-Saharan Africa: The evidence from Nigeria," World Development 40(7): I3821393.

Potts, D. 2006. “Urban growth and urban economies in eastern and southern Africa: Trends and prospects," pp. 67-104 in D.F. Bryceson and D. Potts, eds., African Urban Economies: Viability, Vitality or Vitiation of Major Cities in East and Southern Africa? Houndmills, Basingstoke: Palgrave Macmillan.

Potts, D. 2000. "Urban unemployment and migrants in Africa: Evidence from Harare 1985-1994." Development and Change 31:879-910.

Potts, D. 1995. "Shall we go home? Increasing urban poverty in African cities and migration processes." Geographical Journal I6 I(3):245-264.

Reed, H.E., and B. Mberu. 2014. "The Demography of Ethnicity and Religion in Nigeria," chapter in The International Handbook of the Demography of Race and Ethnicity, Springer Press (forthcoming).

Ross, M.L. 2003. "Nigeria's Oil Sector and the Poor." Paper prepared for the UK Department of International Development 'Nigeria: Drivers of Change' program. May 2003.

UNAIDS. 2008. Report on the Global AIDS Epidemic. Geneva: UNAIDS.

UNESCO. 2000. Education for All: The Year 2000 Assessment: Nigeria Country Report. Available at: http://www.unesco.org/education/wef/ countryreports/nigeria/contents.html, accessed: Wednesday, January 27, 2010.

United Nations.2012. World Population Prospects: The 2012 Revision. Population Division of the Department of Economic and Social Affairs of the United Nations Secretariat,

United Nations. 2009. World Urbanization Prospects: The 2009 Revision. Population Division of the Department of Economic and Social Affairs of the United Nations Secretariat, $h$ ttp://esa.un.org/ wup2009/unup/index.asp, accessed: Friday, March 26, 2010; 2:04:23 PM. New York: United Nations.

White, M.J., S. Muhidin, C. Andrzejewski, E. Tagoe, R. Knight, and H. Reed. 2008. "Urbanization and fertility: An event-history analysis of coastal Ghana." Demography 45(4):803-8I6.

World Bank. 2009. Africa Development Indicators 2008-9: Youth and Employment in Africa, The potential, the Problem, the Promise. Washington, DC: The World Bank.

World Bank/DFID. 2005. Country Partnership Strategy for the Federal Republic of Nigeria. June 2.

World Bank. (1996). Nigeria: Poverty in the midst of plenty: The challenge of growth with inclusion (Report No 14). Washington, DC: World Bank. 